\title{
Middle-Aged Female Diagnosed With Widespread Stiff Skin Syndrome
}

\author{
Aylin SARI'®, Derya ÇIRAKOĞLU²] \\ ${ }^{1}$ Department of Physical Therapy and Rehabilitation, Erenköy Physical Therapy and Rehabilitation Hospital, İstanbul, Turkey \\ ${ }^{2}$ Department of Physical Therapy and Rehabilitation, Ordu University Medical Faculty, Ordu, Turkey
}

A 46-year-old female patient presented with restricted joint movements, swelling in arms and legs, skin stiffness, and whole-body inflexibility. Her complaints had started five years ago and increased since then. She did not have any vascular condition or symptoms indicative of Raynaud's phenomenon (evident skin conditions on her face, coldness in her hands, or cyanosis). There were no prominent skin pigment changes, telangiectases, or any distinctive finger appearance with sclerodactyly or ulceration. Upon inspection, significant bilateral skin thickness and edema were found in her lower extremities. Her skin surface was shiny and irregular. Her range of motion (ROM) was limited for the bilateral shoulder, elbow, wrist, hip, knee, and ankle joints (Figure 1). Laboratory analyses showed normal results for hemogram, routine biochemical tests, erythrocyte sedimentation rate and normal extractable nuclear antibody profile. She had normal levels for muscle enzymes, protein, C-reactive protein, anti-nuclear antibody, rheumatoid factor, antiscleroderma-70, and anti-centromere antibody. Furthermore, radiographs were normal. Doppler ultrasound of the extremities revealed no abnormal findings, except thickness reaching to the subcutaneous tissues. On skin biopsy of the extremities, thickened and enlarged bundles of collagen were found in the dermis. We also found evidences of atrophy in the epidermis, adipocyte entrapment, and non-inflammatory enlargement in the fascia with normal muscle appearance beneath it. Slight accumulations of mucopolysaccharide were identified using the Alcian-blue stain. The patient was identified as having widespread stiff skin syndrome (SSS) as a result of the above-mentioned clinical and pathological findings.

Stiff skin syndrome is a rare kind of scleroderma that is characterized by contracture-like limited joint ROM and thickened stiff skin. ${ }^{1,2}$ It is divided into two categories: widespread SSS and segmental SSS. ${ }^{3}$ Widespread SSS is more severe, more common, has more limited joint ROM, and an earlier onset than segmental SSS. Both widespread SSS and segmental SSS are reported to have early onset within the first six years of life. The patient discussed herein is a rare case because she was diagnosed as an adult. Segmental SSS is predominant in females, whereas widespread SSS does not seem to feature any sex preinclination. Segmental SSS has segmental distribution with unilateral predominance. Compared with widespread SSS,

Received: December 26, 2017 Accepted: January 28, 2018 Published online: March 23, 2018

Correspondence: Aylin Sarı, MD. Erenköy Fizik Tedavi ve Rehabilitasyon Hastanesi, Fiziksel Tıp ve Rehabilitasyon Kliniği, 34736 Erenköy, Kadıköy, İstanbul, Turkey. Tel: +90 216 - 4118011 e-mail: mdaylinsari@gmail.com 

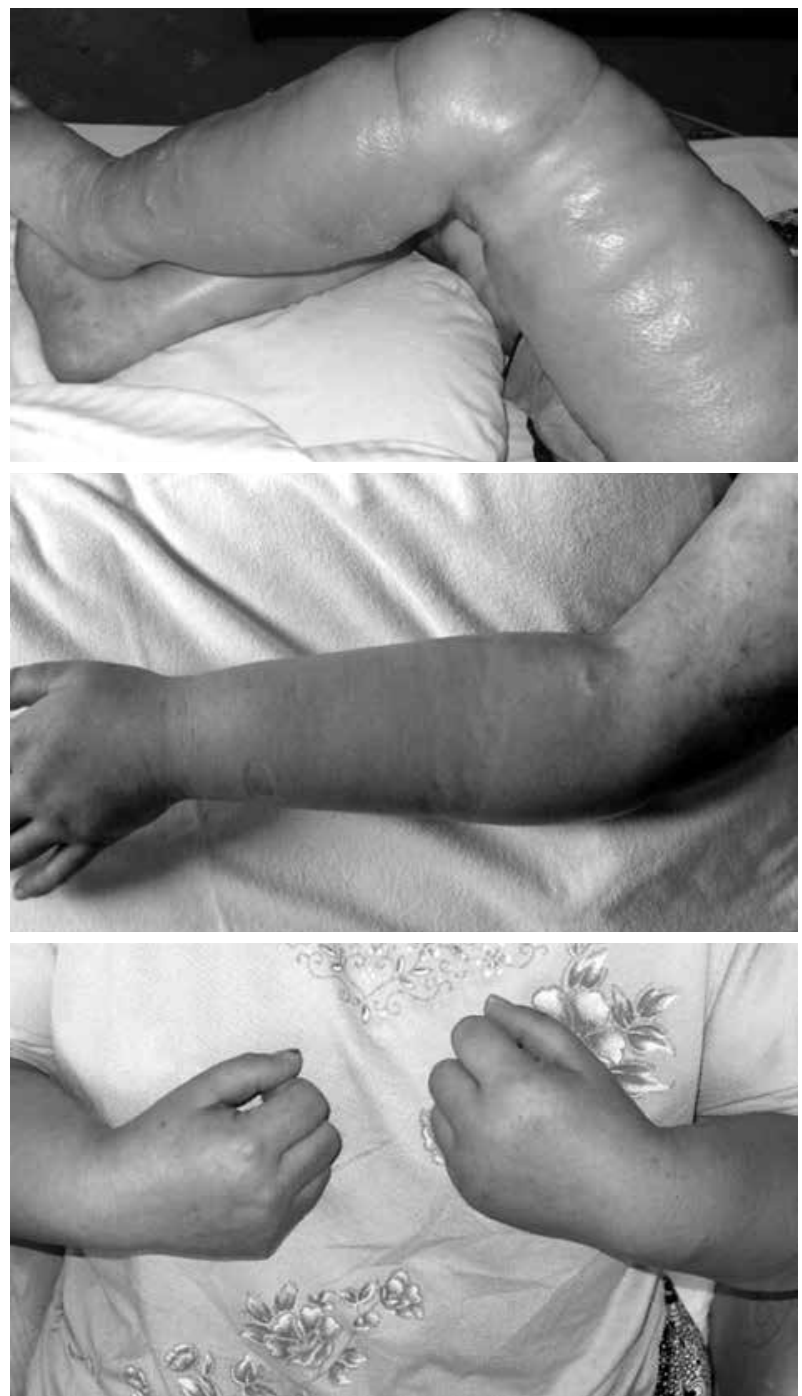

Figure 1. Skin thickness, edema on lower extremities and limited range of motion (elbow and wrist).

limited joint ROM occurs less than half of patients in segmental SSS. ${ }^{3}$

Both categories of SSS may be genetically inherited ( 20\%). In many cases, chest expansion is decreased due to the decreased elasticity and increased thickening of the skin in the thoracic region, causing restrictive changes in the lungs. ${ }^{1-7}$ It is not a progressive disorder; ${ }^{1-8}$ however, two cases reportedly progressed from segmental SSS to widespread SSS.7,9

Therapeutic exercises and rehabilitation programs are suggested for preventing joint contractures. Corticosteroids and other immunosuppressants have proven ineffective. ${ }^{1-9}$
Only mycophenolate mofetil resolved skin lesions and improved joint ROM in two cases. ${ }^{10}$

Our patient underwent active rehabilitation with regularly performing ROM exercises and stretching exercises for alleviating contracture. Wet cold compresses and local corticosteroids were applied to rubescent extremities; oral antihistaminic treatment was administered.

Consequently, SSS is rare and can have different clinical presentations. Overall, further knowledge and experience of this syndrome are required for a better treatment approach.

\section{Declaration of conflicting interests}

The authors declared no conflicts of interest with respect to the authorship and/or publication of this article.

\section{Funding}

The authors received no financial support for the research and/or authorship of this article.

\section{REFERENCES}

1. Esterly NB, McKusick VA. Stiff skin syndrome. Pediatrics 1971;47:360-9.

2. Guiducci S, Manetti M, Romano E, Randone SB, Manneschi LI. Stiff Skin Syndrome. In: Skin Manifestations in Rheumatic Disease. New York: Springer; 2014. p. 239-45.

3. Myers KL, Mir A, Schaffer JV, Meehan SA, Orlow SJ, Brinster NK. Segmental stiff skin syndrome (SSS): A distinct clinical entity. J Am Acad Dermatol 2016;75:163-8.

4. Loeys BL, Gerber EE, Riegert-Johnson D, Iqbal $\mathrm{S}$, Whiteman $\mathrm{P}, \mathrm{McC}$ connell $\mathrm{V}$, et al. Mutations in fibrillin-1 cause congenital scleroderma: stiff skin syndrome. Sci Transl Med 2010;2:23ra20.

5. Jensen SA, Iqbal S, Bulsiewicz A, Handford PA. A microfibril assembly assay identifies different mechanisms of dominance underlying Marfan syndrome, stiff skin syndrome and acromelic dysplasias. Hum Mol Genet 2015;24:4454-63.

6. Deng X, Chen F, Song Z, Yan H, You Y, Zhong B, et al. Four new cases of stiff skin syndrome with unusual presentations. J Eur Acad Dermatol Venereol 2016;30:163-5.

7. Liu T, McCalmont TH, Frieden IJ, Williams ML, Connolly MK, Gilliam AE. The stiff skin syndrome: case series, differential diagnosis of the stiff skin phenotype, and review of the literature. Arch Dermatol 2008;144:1351-9. 
8. Morrell DS, Challgren E, Nijhawan A, Olson J, Laumann A, Medenica M, et al. Two cases for diagnosis: asymmetric childhood scleredema or stiff skin syndrome? Pediatr Dermatol 2003;20:350-5

9. Jablonska S, Blaszczyk M. Scleroderma-like indurations involving fascias: an abortive form of congenital fascial dystrophy (Stiff skin syndrome). Pediatr Dermatol 2000;17:105-10.

10. Kurtzman DJ, Wright NA, Patel M, Vleugels RA. Segmental stiff skin syndrome (SSS): Two additional cases with a positive response to mycophenolate mofetil and physical therapy. J Am Acad Dermatol 2016;75:e237-e239. 